\title{
Determination of the Shortest Route on the Distribution System using Ant Colony Optimization (ACO) Algorithm (Case Study: Alfamidi Palu Branch - PT. Midi Utama Indonesia)
}

\author{
Nabila Dwi Indria ${ }^{\text {a,1,*, Junaidi a,2 }}{ }^{\text {, Iut Tri Utami }}{ }^{\text {a,3 }}$ \\ ${ }^{a}$ Department of Statistics, Universitas Tadulako, Palu, Sulawesi Tengah 94148, Indonesia \\ ${ }^{1}$ nabilaindria5@gmail.com*; ${ }^{2}$ junaidi.untad@gmail.com; ${ }^{3}$ triutami.iut@ gmail.com \\ * corresponding author
}

\section{ARTICLE INFO}

\section{Article history}

Received October 19, 2021

Revised December 14, 2021

Accepted December 17, 2021

Keywords

Ant Colony Optimization

Ant Colony System

Distribution System

Traveling Salesman Problem

\begin{abstract}
The distribution system of goods is one of the most important parts for every company. The company certainly has many route options to visit, and this is expected to be conducted efficiently in terms of time. In the distribution of goods by Alfamidi company in Palu City which has 51 outlets include into the category of Traveling Salesman Problem (TSP) because of many route options that can be visited. The problem can be solved by employing the Ant Colony Optimization (ACO) method which is one of the algorithms Ant Colony System (ACS). The ACS acquires principles based on the behavior of ant colonies and applies three characteristics to determine the shortest route namely status transition rules, local pheromone renewal and global pheromones. The result showed that the shortest route of the distribution of goods based on the calculation of selected iterations was ant 1 with the shortest total distance obtained $86.98 \mathrm{~km}$.
\end{abstract}

\section{Introduction}

Distribution of goods is tremendously important for every company. The ever-evolving industry encourages providers of products or services to continuously improve the capabilities of services by maintaining quality and providing products or services as quickly and easily accessible to all users. Every company certainly requires a courier to deliver stock of these goods, and of course in delivering the goods a courier will have many route options, and in the distribution of goods, it is certainly expected to be efficient, both in terms of time and cost [1].

The Alfamidi Palu Branch is part of PT. Midi Utama Indonesia TBK and built quite a number of outlets spread almost in every corner of Palu City. The location of the outlet is divided into 8 subdistricts based on the database owned by the company. The number of outlets should be visited to distribute of goods. The distribution of goods has to be conducted efficiently. The optimization of route from one location to another can be carried out by Alfamidi using the problem of Traveling Salesman Problem (TSP). 
TSP is one of the problems of combinatorial optimization. The principle of TSP is how a salesman can visit all locations in an area exactly once and must return to the initial location of departure with a minimum distance [2]. TSP is included in the NP-hard problem. Therefore, the heuristic approach can be utilized to solve the problem. Heuristic is a method that uses a system approach in searching in optimization. One of the known heuristic methods is the Ant Colony Optimization (ACO) algorithm. The ACO is tremendously appropriate to be applied in solving optimization problems by determination the shortest path of the TSP problem. Providing the principle of its algorithm is based on the behavior of ant colonies in finding the shortest travel distance [3]. The ACO is a technique that obtains inspiration from nature. In this case, the behavior of ants is observed in finding the shortest route from the nest to the place of food, modeling each ant walking to visit a place and leaving a pheromone substance on the route their passed [4].

Mulia (2011) [5] solved the problem about the Ant System algorithm by applying TSP. She obtained the total distance of traveled was $161.48 \mathrm{~km}$. Another study was conducted by Tutupary (2014) on the application of Ant Colony Optimization algorithm in determining the distribution of FUEL in PT. Seabirds obtained the optimal distance traveled was 5.262 miles. Mindaputra (2009) [6] used the ACS algorithm in TSP at PT. Eka Jaya Motor. He obtained the total distance traveled was 52.53 meters. Paillin (2017) [7] determined the optimal route of distribution of nestle products using the TSP method and he obtained 5 optimal routes that are $8.09 \mathrm{~km}, 9.47 \mathrm{~km}, 10.88 \mathrm{~km}, 9.74 \mathrm{~km}$, and $19.87 \mathrm{~km}$, respectively.

TSP is tremendously difficult to solve, especially for problems with a large number of locations [3]. Based on this, the resolution of the TSP problem administering the ACO method with the ACS algorithm is required for Alfamidi Palu Branch to determine the shortest route in order to distribute of goods to each location of outlets scattered in Palu. This research will use indicator such as store and route data in the form of coordinate point data for each Alfamidi Palu outlet location.

\section{Theory}

\subsection{Teori Graf}

Graph theory is one of the branches of mathematics that is useful for a wide application in everyday life, including graph coloring and finding the shortest path. An algorithm is needed to solve problems that are represented in the form of a graph [8]. If the graph is represented in the form of a matrix, for example, $\mathrm{G}$ is a graph consisting of $\mathrm{n}$ vertices, the connectedness matrix corresponding to the graph $\mathrm{G}$ is a square matrix of $\mathrm{n} \times \mathrm{n}$ [9].

\subsection{Traveling Salesman Problem (TSP)}

Traveling Salesman Problem (TSP) is a combinatorial problem that has been widely studied. TSP is a condition where a traveling salesman must visit $n$ cities with the rule that he must visit each city only once, minimizing the total distance traveled and in the end he must return to his hometown.

TSP is represented by using a complete graph and weighted $G=(V, E)$ with $V$ representing the set of vertices and $E$ being the set of edges. Each edge $(i, j) \in E$ is the distance of $d_{i j}$ from location $i$ to location $\mathrm{j}$, where $(i, j) \in V$, in symmetrical TSP (distance from location $i$ to point $\mathrm{j}$ is equal to the distance from point $\mathrm{j}$ to point $\mathrm{i}) \mathrm{d}_{\mathrm{ij}}=\mathrm{d}_{\mathrm{ji}}$ for all sides (i,j) $\in \mathrm{E}$ (Leksono, 2009) [3].

\subsection{Ant Colony System (ACS)}

Ant Colony System Algorithm is an algorithm composed of a number of $m$ ants that work together and communicate indirectly through pheromone communication. The three main characteristics of the Ant Colony System (ACS) algorithm are as follows:

\section{State transition rules}

If $q \leq q_{0}$ then the selection of the point to be addressed applies the rules in the equation:

$$
\begin{aligned}
& \text { Temporary }(\mathrm{t}, \mathrm{u})=\left[\tau_{0}\left(\mathrm{t}, \mathrm{u}_{\mathrm{i}}\right)\right] \cdot\left[\eta\left(\mathrm{t}, \mathrm{u}_{\mathrm{i}}\right)\right]^{\beta}, \mathrm{i}=1,2,3, \ldots, \mathrm{n} \\
& \mathrm{v}=\max \quad\left\{\left[\tau\left(\mathrm{t}, \mathrm{u}_{\mathrm{i}}\right)\right]\left[\eta\left(\mathrm{t}, \mathrm{u}_{\mathrm{i}}\right)^{\beta}\right]\right\}
\end{aligned}
$$


If $\mathrm{q}>\mathrm{q}_{0}$ the equation will be used as follows:

$$
\text { Probability }(\mathrm{t}, \mathrm{u})=\frac{\left[\tau\left(\mathrm{t}, \mathrm{u}_{\mathrm{i}}\right)\right] \cdot\left[\eta\left(\mathrm{t}, \mathrm{u}_{\mathrm{i}}\right)^{\beta}\right]}{\sum_{\mathrm{i}=1}^{\mathrm{n}}\left[\tau_{0}\left(\mathrm{t}, \mathrm{u}_{\mathrm{i}}\right)\right] \cdot\left[\eta\left(t, \mathrm{u}_{\mathrm{i}}\right)\right]^{\beta}}
$$

for

$$
\eta\left(t, u_{i}\right)=\frac{1}{\operatorname{distance}\left(\eta\left(t, u_{i}\right)\right.}
$$

where:

$\mathrm{u} \quad$ : point to go

$\tau(\mathrm{t}, \mathrm{u}) \quad$ : value of the pheromone trace at the point $(\mathrm{t}, \mathrm{u})$

$\eta(t, u) \quad$ : inverse of the distance from city t to city $u$

$\mathrm{p}_{\mathrm{m}}(\mathrm{t}, \mathrm{u})$ : probability that ant $m$ chooses to move from point $\mathrm{t}$ to point $\mathrm{u}$

$\beta \quad$ : remote control parameters $(\beta \geq 0)$

2. Local pheromone renewal rules

While on a tour to find the solution of the TSP, the ants visit the edges and change the pheromone levels on those edges by applying the local pheromone renewal rule shown by the following equation:

$$
\tau(t, v) \leftarrow(1-\rho) \cdot \tau(t, v)+\rho \cdot \Delta \tau(t, v)
$$

with,

$$
\Delta \tau(\mathrm{t}, \mathrm{v})=\frac{1}{\mathrm{Lnn}_{\mathrm{nn}} \cdot \mathrm{c}}
$$

where:

$L_{n n} \quad$ : tour length obtained

$c \quad$ : number of locations

$v \quad:$ point to go

$\rho \quad$ : parameter with values 0 to 1

$\Delta \tau \quad$ : pheromone changes

3. Global pheromone renewal rules

In this system, global pheromone renewal is only performed by the ants making the shortest tour since the start of the experiment. At the end of an iteration, after all the ants have completed their tour, a number of pheromones are placed on the edges that an ant has passed through which has found the best tour or the other edges are not changed.

The pheromone level is updated by applying the global pheromone renewal rule which is shown by the following equation:

$$
\tau(\mathrm{t}, \mathrm{v}) \leftarrow(1-\alpha) \cdot \tau(\mathrm{t}, \mathrm{v})+\alpha \cdot \Delta \tau(\mathrm{t}, \mathrm{v})
$$

with

$$
\Delta \tau(t, v)= \begin{cases}\mathrm{L}_{\mathrm{gb}}{ }^{-1} & \text { if }(\mathrm{t}, \mathrm{v}) \in \text { the best tour } \\ 0 & \text { if }(\mathrm{t}, \mathrm{v}) \in \text { the best tour }\end{cases}
$$

where:

$\tau(t, v)$ : the final pheromone value after experiencing a local update

$L_{g b} \quad$ : the best tour path length at the end of the tour

$\alpha \quad$ : parameters controlling the intensity of the ant trail

$\leftarrow \quad$ : tend to

$\Delta \tau \quad:$ pheromone changes

\section{Method}

\subsection{Research Location}

The research site is in Alfamidi, PT. Midi Utama Indonesia Central Sulawesi Palu Branch. 


\subsection{Data}

The data used in this study was secondary data in the form of TSP data. The store data was obtained from Alfamidi Office Palu branch. The route data which shows the coordinate points was obtained by the help of Google Maps. The TSP data is presented in Table 1.

Table 1. Research Variables

\begin{tabular}{cl}
\hline Description of Variables & \multicolumn{1}{c}{ Operational definition } \\
\hline Location coordinate point & $\begin{array}{l}\text { The coordinate points referred to in this study are all } \\
\text { Alfamidi outlet points in Palu City. }\end{array}$ \\
\hline \multirow{3}{*}{ Store data } & $\begin{array}{l}\text { The data included in the store data is the number of } \\
\text { outlets, outlet code, and Alfamidi outlet address in Palu } \\
\text { City. }\end{array}$ \\
\hline
\end{tabular}

\subsection{Methods of Analysis}

The data analysis in this study employed the Ant Colony Optimization (ACO) Method. The steps of analysis are as follows:

a. Collect data from each point using coordinate data $(\mathrm{X}, \mathrm{Y})$ with the help of Google Maps.

b. Describe the coordinate points of each location into a graph.

c. Represent graphs into matrix forms by calculating Euclidean distances using latitude and longitude points is then converted into $\mathrm{km}$ units by multiplying the value of $1^{\circ}$ of the earth $=111.319 \mathrm{~km}$.

d. Search for the shortest trajectory of all points using the Ant Colony Optimization (ACO) method with the completion of the Ant Colony System Algorithm (ACS).

e. Conclude the results of the study.

\section{Result and Discussion}

\subsection{Data Collection}

Data retrieval in the form of coordinate points using latitude and longitude with the help of Google Maps is the first step conducted. This is based on the database owned by the company for each location point. An example of coordinate point search results is given in Fig. 1 and Fig. 2.

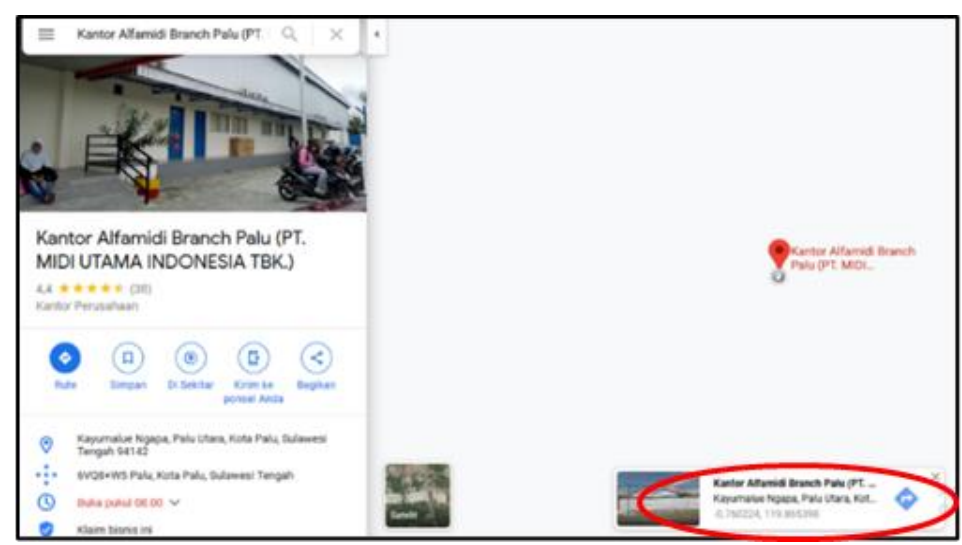

Fig. 1. Gudang Alfamidi [GDG] coordinate point. 


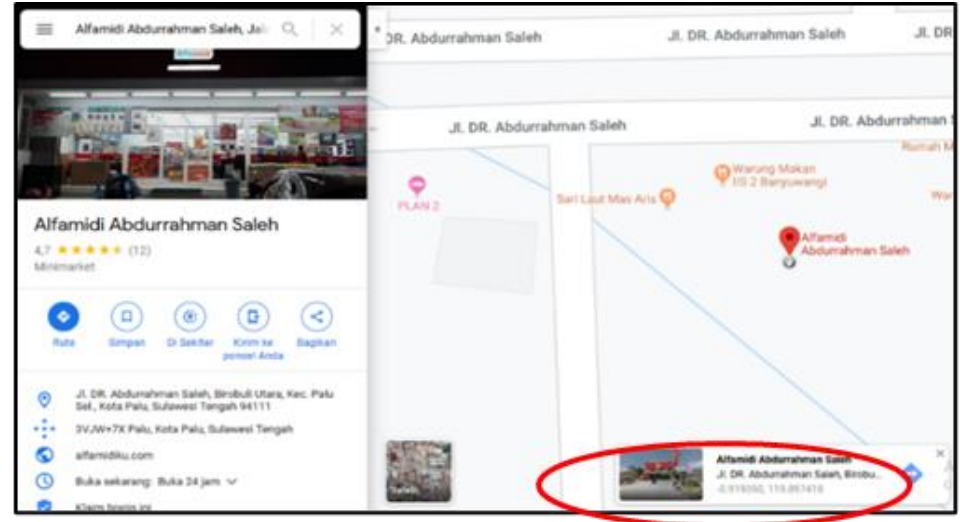

Fig. 2. Alfamidi Abdurrahman Saleh $[\mathrm{ABS}]$ coordinate point.

On Fig. 1 it can be seen that the coordinate points of Alfamidi warehouse located at Jl. Kayumalue Ngapa, North Palu. This warehouse is located at x (latitude): -0.7602 and y (longitude): 119.8653. Moreover, on Fig. 2 it can be seen that the coordinate point of Alfamidi Abdurrahman Saleh [ABH] outlet located at Jl. Abdurrahman Saleh, North Birobuli. This is located at x (latitude): -0.9193 and y (longitude): 119.8974, as well as for 50 other locations to be visited.

\subsection{Track Map in Graph Form}

Once the coordinate point is obtained from each location point, it will then be formed into a graph. The creation of a path map in the form of a graph is completed with the help of software using coordinate points that have been obtained previously. Fig. 3 is a map of the path of the location of Alfamidi warehouses and outlets displayed in the form of graphs.

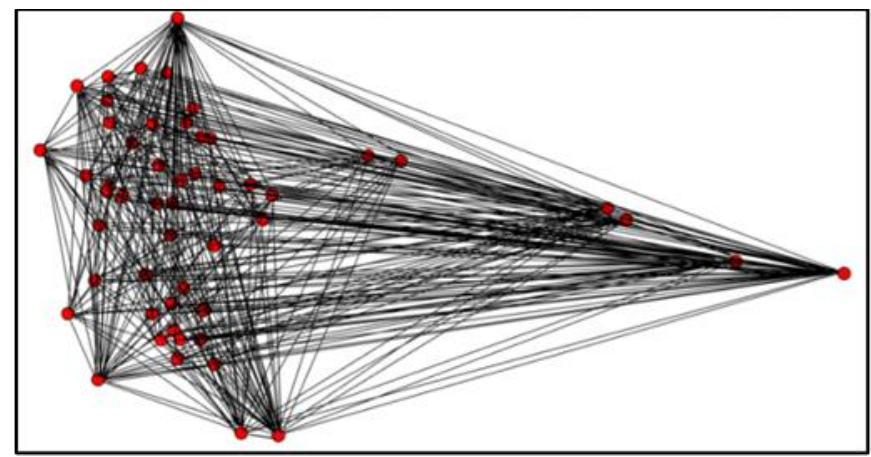

Fig. 3. Path map in graph form.

Fig. 3 is a map of the path of 51 outlets and 1 Alfamidi warehouse in Palu City depicted using the help of graphs. Each point is interconnected with each other, and each side has different weights according to the distance of each location. The distance calculation is provided subsequently.

\subsection{Graph Representation}

The relationship between each point on the graph is formed in an $n \times n$ matrix. The calculation is carried out using Euclidean distance which calculates the distance of two coordinate points (latitude and longitude). The calculation is given as follows.

Suppose the coordinates of location 1 is Alfamidi warehouse which in this case is point i located at $\mathrm{x}$ : -0.7602 and $\mathrm{y}: 119.8653$. Moreover, the coordinates of location 2 is Alfamidi Abdurahman Saleh $[\mathrm{ABH}]$ outlets which in this case is point $\mathrm{j}$ located at $\mathrm{x}:-0.9193$ and $\mathrm{y}: 119.8974$. 


$$
\begin{aligned}
\mathrm{d}_{\mathrm{ij}} & =\sqrt{\left(\mathrm{x}_{\mathrm{i}}-\mathrm{x}_{\mathrm{j}}\right)^{2}+\left(\mathrm{y}_{\mathrm{i}}-\mathrm{y}_{\mathrm{j}}\right)^{2}} \\
\mathrm{~d}_{12} & =\sqrt{\left(\mathrm{x}_{1}-\mathrm{x}_{2}\right)^{2}+\left(\mathrm{y}_{1}-\mathrm{y}_{2}\right)^{2}} \\
& =\sqrt{(-0.760224-(-0.9193))^{2}+(119.8653-119.8974)^{2}} \\
& =\sqrt{(0.1591)^{2}+(-0.0320)^{2}} \\
& =\sqrt{0.02532+0.0010} \\
& =\sqrt{0.0263} \\
& =0.1623
\end{aligned}
$$

From the calculation, we obtained the value $\mathrm{d}_{12}=0.1623$. This is the Euclidean distance from the location of Alfamidi warehouse and Alfamidi Abdurrahman Saleh [ABH] outlet. The distance is still in the form of decimal degree units then adjusted utilizing the value of $1^{\circ}$ earth $=111.319 \mathrm{~km}$. We obtained

$$
\begin{aligned}
& =0.1623 \times 111.319 \mathrm{~km} \\
& =18.0689 \mathrm{~km}
\end{aligned}
$$

Thus, the distance from Alfamidi warehouse to Alfamidi Abdurrahman Saleh [ABH] outlet is $18.0689 \mathrm{~km}$. Other data to determine the distance matrix values for all locations is performed using software.

\subsection{Determining the Shortest Route of Distribution of Goods Using Ant Colony System Algorithm}

Before entering the ACS algorithm, the first step which must be completed is to determine the value of the parameters on the algorithm. In this study, the parameters used are based on the value of previous research by Leksono (2009) [3].

The following parameters for pheromones controllers are $\alpha=0.1$, distance control parameters are $\beta=2$, evaporation rate values $\rho=0.1$, and the number of ants $m=10$. These then will be performed 10 iterations. The ACS algorithm has three main characteristics in completing the determination of the shortest route as given as follows:

a. Status Transition Rules

The status transition rule is the stage of selection of the point to be addressed. At this stage, the transport can placed at the point $t$ to go to the point $u$. The value of visibility is calculated as follows:

$$
\begin{aligned}
\eta_{i j} & =\frac{1}{d_{i j}} \\
\eta_{12} & =\frac{1}{d_{12}} \\
& =\frac{1}{18.0689} \\
& =0.0553
\end{aligned}
$$

We then calculate the visibility value for the distance of the warehouse location to the location of Abdurahman Saleh's outlet. We obtain $\eta_{1,2}=0,0553$ with the inverse value of the distance of each location. Complete data related to the value of visibility is done by using software.

We next choose the point $t$ to go to $u$. At this stage, the value of beta is determined by $\beta=2$, and the pheromone value in the initial calculation is set with a very small value for the entire point of $\tau=$ 0.0001 . Here is the result of the calculation of temporary values and probability values, for example, 
from the warehouse (GDG) location point in this case it is at point $\mathrm{t}$ to Alfamidi Abdurahman Saleh (SJ02) which is at point $u$ can be seen as follows:

$\operatorname{Temporary}(\mathrm{t}, \mathrm{u})=\left[\tau\left(\mathrm{t}, \mathrm{u}_{\mathrm{i}}\right)\right] \cdot\left[\eta\left(\mathrm{t}, \mathrm{u}_{\mathrm{i}}\right)\right]^{\beta}, i=1,2,3, \ldots, n$

$$
\mathrm{v}=\max \left\{\left[\tau\left(\mathrm{t}, \mathrm{u}_{\mathrm{i}}\right)\right]\left[\eta\left(\mathrm{t}, \mathrm{u}_{\mathrm{i}}\right)^{\beta}\right]\right\}
$$

Temporary $\left(\right.$ GDG,SJ02) $=\left[\tau(\right.$ GDG,SJ02) $] \cdot[\eta(G D G, S J 02)]^{\beta}$

$$
\begin{aligned}
& =[0.0001] \cdot[0,0553436418913321]^{2} \\
& =3.06292 \times 10^{7}
\end{aligned}
$$

We then obtained a temporary value from the location of Alfamidi warehouse to Abdurrahman Saleh outlet $3.06292 \times 10^{7}$. Furthermore, the example of the calculation for the probability value with the starting point of the warehouse [GDG] in this case is at point $t$ and $u$ is the point to be addressed as follows:

$$
\begin{aligned}
& \text { Probabilities }(\mathrm{t}, \mathrm{u})=\frac{\left[\tau\left(\mathrm{t}, \mathrm{u}_{\mathrm{i}}\right)\right] \cdot\left[\eta\left(\mathrm{t}, \mathrm{u}_{\mathrm{i}}\right)^{\beta}\right]}{\sum_{\mathrm{i}=1}^{\mathrm{n}}\left[\tau\left(\mathrm{t}, \mathrm{u}_{\mathrm{i}}\right)\right]\left[\eta\left(\mathrm{t}, \mathrm{u}_{\mathrm{i}}\right)^{\beta}\right]} \\
& \sum_{\mathrm{n}}^{\mathrm{n}}\left[\tau\left(\mathrm{t}, \mathrm{u}_{\mathrm{i}}\right)\right]\left[\eta\left(\mathrm{t}, \mathrm{u}_{\mathrm{i}}\right)^{\beta}\right]==\text { total temporary for Warehouse point" } \\
&= 3,0629 \times 10^{7}+3,17744 \times 10^{7}+1,07665 \times 10^{6}+4,61966 \times 10^{7}+ \\
& 4,24235 \times 10^{7}+7,08786 \times 10^{6}+3,93826 \times 10^{7}+5,78716 \times 10^{7}+ \\
& 3,31334 \times 10^{7}+3,72213 \times 10^{7}+9,83166 \times 10^{6}+1,05827 \times 10^{5}+ \\
& 4,04285 \times 10^{7}+3,05356 \times 10^{7}+2,94556 \times 10^{7}+3,73731 \times 10^{7}+ \\
& 4,2847 \times 10^{7}+3,03771 \times 10^{7}+3,12858 \times 10^{7}+2,56498 \times 10^{7}+ \\
& 3,60006 \times 10^{7}+2,80724 \times 10^{7}+3,09225 \times 10^{7}+3,1507 \times 10^{7}+ \\
& 3,66954 \times 10^{7}+2,80144 \times 10^{7}+4,03762 \times 10^{7}+5,26866 \times 10^{7}+ \\
& 4,65664 \times 10^{7}+3,69996 \times 10^{7}+4,10831 \times 10^{7}+3,3804 \times 10^{7}+ \\
& 3,59855 \times 10^{7}+3,08504 \times 10^{7}+3,38143 \times 10^{7}+4,44231 \times 10^{7}+ \\
& 3,68774 \times 10^{7}+3,77069 \times 10^{7}+4,11683 \times 10^{7}+3,97021 \times 10^{7}+ \\
& 4,32944 \times 10^{7}+4,53735 \times 10^{7}+3,92569 \times 10^{7}+4,42511 \times 10^{7}+ \\
& 5,62129 \times 10^{7}+3,94347 \times 10^{7}+4,02865 \times 10^{7}+4,86283 \times 10^{7}+ \\
& 3,92229 \times 10^{7}+5,58965 \times 10^{7}+8,93756 \times 10^{7} \\
&= 4,7289 \times 10^{5}
\end{aligned}
$$

$\frac{\left[\tau\left(\text { Warehouse, SJ02]. }\left[\eta(\text { Warehouse,SJ02) })^{\beta}\right]\right.\right.}{\text { "total temporary for point" (Warehouse) }}=\frac{3,06292 \times 10^{7}}{4,7289 \times 10^{5}}$

$$
=0,0064
$$

We obtained the probability value for the starting point of Alfamidi warehouse to Alfamidi Abdurrahman Saleh outlet 0.0064. Furthermore, the determination of random number (q) and set the limiting number $\left(\mathrm{q}_{0}\right)$ is carried out as given below. 
In this case, the random number $\mathrm{q}=0.09$ is assigned a value $\mathrm{q}_{0}=0,91$ from here it can be seen that $\mathrm{q}_{0}$ is greater than $\mathrm{q}$, so we next determine the point by looking at the largest temporary result.

Hence, the next selected location is point 13 or Alfamidi Tawaeli [TWI] outlet which is located at Jl. Trans Sulawesi, Panau with a value of temporary (Warehouse, SJ34) $=0.00001058$. The results of the overall temporary calculation can be performed by sorting the next largest temporary value up to the last route. The calculation of stage 1 has been passed then the first iteration for the first ant has been completed. In the following, the pheromone renewal stage will be discussed.

\section{b. Local Pheromone Reform Stage $(\tau)$}

At this stage, the pheromones are renewed locally and the results will be employed for the next iteration. Here is an example of calculations $t$ for warehouses (GDG) and $v$ for Alfamidi Tawaeli outlets (SJ34).

Warehouse Location - SJ34

$\Delta \tau(\mathrm{t}, \mathrm{v})=\frac{1}{\mathrm{~L}_{\mathrm{nn}} \cdot \mathrm{c}}$

$\Delta \tau(\mathrm{GDG}, \mathrm{SJ} 34)=\frac{1}{3,07 \times 52}=0,0063$

$\tau(\mathrm{t}, \mathrm{v}) \leftarrow(1-\rho) \cdot \tau(\mathrm{t}, \mathrm{v})+\rho . \Delta \tau(\mathrm{t}, \mathrm{v})$

$\tau(\mathrm{GDG}, \mathrm{SJ} 34) \leftarrow(1-0,1) . \tau(\mathrm{GDG}, \mathrm{SJ} 34)+0.1 . \Delta \tau(\mathrm{GDG}, \mathrm{SJ} 34)$

$\tau(\mathrm{GDG}, \mathrm{SJ} 34) \leftarrow(1-0,1) \cdot 0,0001+0,1 .(0,0063)$

$\tau(\mathrm{GDG}, \mathrm{SJ} 34) \leftarrow 0,000715598$

We obtained the value of local pheromones renewal for the starting point of the warehouse to Alfamidi Tawaeli outlets 0.000715598 . Once stage 2 is complete then the new pheromones can be used for the next iteration then return to stage 1 for the determination of the shortest route in the second iteration. The process will continue to repeat until the last iteration. We finally obtained the shortest route with the optimal distance of each ant.

\section{c. Global Pheromone Reform Stage $(\tau)$}

After stages 1 and 2 are completed, we then want to obtain the shortest routes and each path that has gone through the pheromone change locally. At this stage we will only update the route with the best results, or it can be said the route with the shortest distance. Based on the results of iterations, the 1 st ant or the first iteration is selected as a route with optimal distance. Here is the shortest route a salesman has to go: GDG - SJ34 - SJ27 - SJ15 - SJ06 - SJ10 - SJ20 - SJ05 - SJ22 - SJ23 - SJ09 SJ62 - SJ18 - SJ24 - SJ53 - SJ48 - SJ60 - SJ11 - SJ33 - SJ45 - SJ16 - SJ17 - SJ28 - SJ14 - SJ25 - SJ07 - SJ56 - SJ30 - SJ37 - SJ08 - SJ61 - SJ51 - SJ02 - SJ47 - SJ38 - SJ41 - SJ42 - SJ26 - SJ21 - SJ03 - SJ54 - SJ12 - SJ52 - SJ01 - SJ49 - SJ31 - SJ19 - SJ50 - SJ32 - SJ29 - SJ04 - SJ40 GDG. From the route obtained the distance to be traveled is $86.98 \mathrm{~km}$.

An example of calculation of global pheromones change is given as follows: the parameter value for the pheromone controller $\alpha=0.1$ and the value for $\mathrm{L}_{\mathrm{gb}}=86.98 \mathrm{~km}$. This is the best track length at the end of the tour. Thus, for (t, v) part of the shortest route i.e.: $\Delta \tau(\mathrm{t}, \mathrm{v})=\mathrm{Lgb}-1=$ $(86,98)-1=0,011497$.

Furthermore, for instance, the global pheromone renewal at the Warehouse point (GDG) to Alfamidi Tawaeli (SJ34) is calculated as follows:

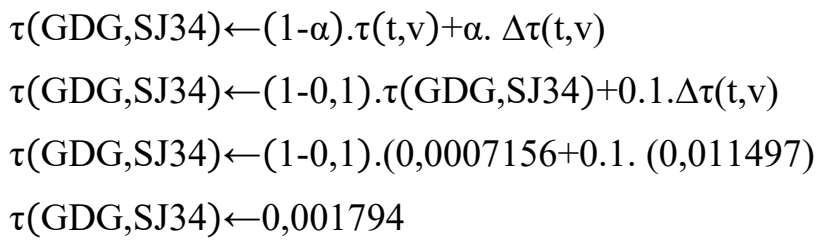


Based on the calculations above, the results obtained from the renewal of global pheromones for warehouse points (GDG) to Alfamidi Tawaeli (SJ34) is 0.001794. Then, the local pheromone value has previously been updated utilizing the new pheromone value.

The $(t, v)$ is not part of the shortest route then used " $\Delta \tau(\mathrm{t}, \mathrm{v})=0$ ", so for example, we will use warehouse (GDG) point and Alfamidi Abdurrahman Saleh (SJ02) as the case of test. This is because the path is not included from the shortest route to be traversed by ants. The obtained result of calculation is as follows:

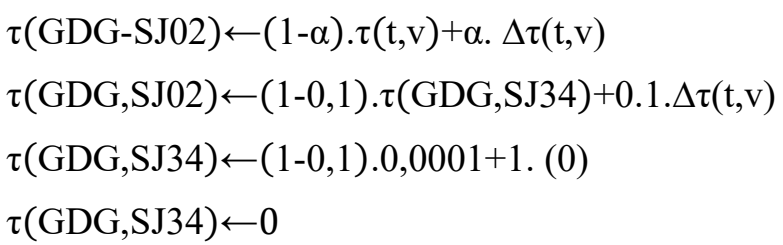

Based on the calculation obtained, the result of the renewal of global pheromones for warehouse points (GDG) to Alfamidi Abdurrahman Saleh (SJ34) outlets is 0. It can then be concluded that all lanes that are not included from the shortest route have a pheromone value of 0 , and for the path included in the shortest route has been updated based on the stage of pheromone renewal globally. The results of calculations for other global pheromones are performed using software.

The overall stage of the Ant Colony System (ACS) algorithm using 10 iterations or 10 ants has been completed and a solution in the form of the shortest route is the result of iteration of ants 1 . Fig 4 is a map of the path of distribution of goods by Alfamidi in the form of graphs after going through the calculation stage.

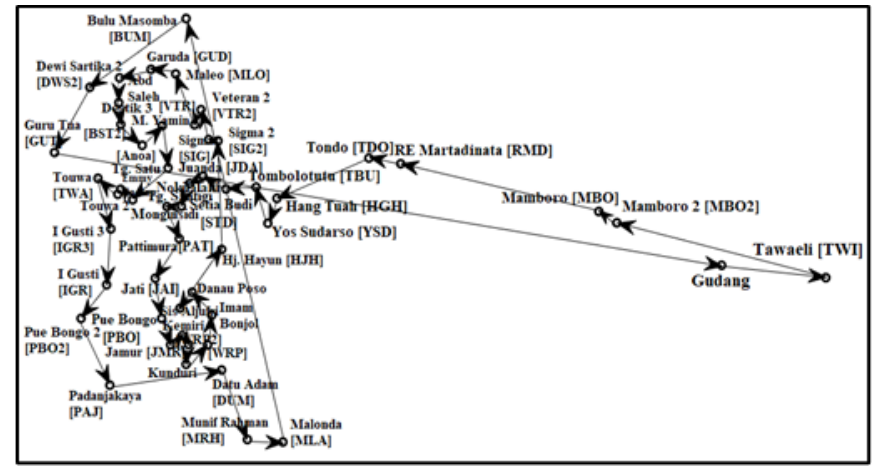

Fig. 4. Shortest route graph view.

According to Fig. 4, we obtained the shortest route Warehouse $\rightarrow$ Tawaeli $\rightarrow$ Mamboro $2 \rightarrow$ Mamboro $\rightarrow$ Martadinata $\rightarrow$ Tondo $\rightarrow$ Hang Tuah $\rightarrow$ Yos Sudarso $\rightarrow$ Tombolotutu $\rightarrow$ Setia Budi $\rightarrow$ Airport $\rightarrow$ Nokilalaki $\rightarrow$ Tg. Santigi $\rightarrow$ Wolter Monginsidi $\rightarrow$ Patimura $\rightarrow$ Jati $\rightarrow$ Pue Bongo $\rightarrow$ Jamur $\rightarrow$ Kemiri $\rightarrow$ WR. Supratman $2 \rightarrow$ Kunduri $\rightarrow$ WR. Supratman $\rightarrow$ Imam Bonjol $\rightarrow$ Danau Poso $\rightarrow$ Sis Aljufri $\rightarrow$ H.Hayun $\rightarrow$ Sisimangaraja $2 \rightarrow$ Sisimangaraja $\rightarrow$ Veteran $2 \rightarrow$ Veteran $\rightarrow$ Maleo $\rightarrow$ Garuda $\rightarrow$ Abdurrahman Saleh $\rightarrow$ Dewi Sartika $3 \rightarrow$ Basuki Rahmat $2 \rightarrow$ Anoa $\rightarrow$ M. Yamin $\rightarrow$ Tanjung Satu $\rightarrow$ Emmy Saelan $\rightarrow$ Basuki Rahmat $\rightarrow$ Touwa $2 \rightarrow$ Touwa $\rightarrow$ I Gusti Ngurahrai $3 \rightarrow$ I Gusti Ngurahrai $\rightarrow$ Pue Bongo $\rightarrow$ Padanjakaya $\rightarrow$ Datu Adam $\rightarrow$ Munif Rahman $\rightarrow$ Malonda $\rightarrow$ Bulu Masomba $\rightarrow$ Dewi Sartika $2 \rightarrow$ Guru Tua $\rightarrow$ Alfamidi Warehouse.

\section{Conclusion}

Based on the results and discussions which have been conducted previously, we can conclude that the determination of the distribution system of goods in the case of Alfamidi Palu city branch with 52 location points includes into the category of Traveling Salesman Problem (TSP) problems. This can be then solved using the Ant Colony Optimization (ACO) method, which is the Ant Colony System (ACS) algorithm by using three main characteristics in determining the shortest route. The results showed the shortest route of distribution of goods (the total distance) is $86.98 \mathrm{~km}$. 


\section{References}

[1] R. Alexander, "Pencarian Rute Distribusi Barang Menggunakan Algoritma Semut," Universitas Sanata Dharma, Jakarta, 2015.

[2] O. Farisi, "Penyelesaian Multi-Depot Multiple Traveling Salesmen Problem Menggunakan K-Means dan Ant Colony Optimization," Jurnal Nusantara, vol. 2, no. 5, pp. 1-8, 2016.

[3] A. Leksono, "Algoritma Ant Colony Optimization (ACO) untuk Menyelesaikan Traveling Salesmen Problem (TSP)," Universitas Diponegoro, Semarang, 2009.

[4] A. Adha, "Peta Interaktif Pencarian Jalur Terpendek dengan Menggunakan Algoritma Semut untuk Penjemputan Barang," Universitas Islam Negeri Sultan Syarif Kasim, Pekanbaru, 2010.

[5] D. Mulia, "Aplikasi Algoritma Ant System (AS) dalam Kasus Traveling Salesmen Problem (TSP)," Universitas Islam Negeri Syarief Hidayatullah, Jakarta, 2011.

[6] E. Mindaputra, "Penggunaan Algoritma Ant Colony System dalam Traveling Salesman Problem (TSP) pada PT. Eka Jaya Motor," Universitas Diponegoro, Semarang, 2009.

[7] D. B. Painlin, "Penentuan Rute Optimal Distribusi Produk Nestle dengan Metode Traveling Salesman Problem (TSP) (Studi Kasus: PT. Paris Jaya Mandiri)," Jurnal Arika, vol. 11, no. 1, pp. 35-43, 2017.

[8] J. S. Budayasa, Teori Graph dan Aplikasinya, Surabaya: Unesa University Press, 2017.

[9] J. S. Siang, Matematika Diskrit dan Aplikasinya Pada Ilmu Komputer, Yogyakarta: Penerbit Andi, 2002. 